\title{
Cytotoxicity and DNA damage in mouse macrophages exposed to silica nanoparticles
}

\author{
H. Yang ${ }^{1}$, Q.Y. Wu ${ }^{1,2}$, C.S. Lao ${ }^{1}$, M.Y. Li ${ }^{1}$, Y. Gao ${ }^{1}$, Y. Zheng ${ }^{1}$ and B. Shi ${ }^{3}$ \\ ${ }^{1}$ Key Laboratory of Environmental Medicine and Engineering, \\ Ministry of Education, School of Public Health, Southeast University, \\ Nanjing, China \\ ${ }^{2}$ School of Public Health, Xuzhou Medical College, Xuzhou, China \\ ${ }^{3}$ School of Medicine, Southeast University, Nanjing, China \\ Corresponding author: H. Yang \\ E-mail: yanghongr@seu.edu.cn
}

Genet. Mol. Res. 15 (3): gmr.15039005

Received July 21, 2016

Accepted August 1, 2016

Published August 30, 2016

DOI http://dx.doi.org/10.4238/gmr.15039005

Copyright $(2016$ The Authors. This is an open-access article distributed under the terms of the Creative Commons Attribution ShareAlike (CC BY-SA) 4.0 License.

ABSTRACT. Silica $\left(\mathrm{SiO}_{2}\right)$ nanoparticles are being progressively
applied in various applications, including cosmetics, food technology,
and medical diagnostics. Although crystalline $\mathrm{SiO}$ is a known
carcinogen, the carcinogenicity of $\mathrm{SiO}_{2}$ nanoparticles remains unclear.
Here, we assessed the cytotoxic effects and DNA injury induced by
exposure to various dosages of $\mathrm{SiO}_{2}$ nanoparticles at $0-2400 \mu \mathrm{g} / \mathrm{mL}$
$\left(0-3200 \mu \mathrm{g} / \mathrm{mL}\right.$ microscale $\mathrm{SiO}_{2}$ as positive control) for $24 \mathrm{~h}$ using
$\mathrm{RAW} 264.7$ cells, followed by methyl tetrazolium (MTT) assay. Cells
were also treated by $31.25,125$, and $500 \mu \mathrm{g} / \mathrm{mL} \mathrm{SiO}$ nanoparticles
$\left(500 \mu \mathrm{g} / \mathrm{mL}\right.$ microscale $\mathrm{SiO}_{2}$ as positive control) for $24 \mathrm{~h}$ and examined
by single cell gel electrophoresis assay (SCEG) and flow cytometry.
Outstanding dose-related decline in cell viability was observed with
enhancing dosages of $\mathrm{SiO}_{2}$ nanoparticles by MTT assay. The inhibitory
concentration $50 \%$ of $\mathrm{SiO}_{2}$ nanoparticles and microscale $\mathrm{SiO}_{2}$ was 
16690 and $5080 \mu \mathrm{g} / \mathrm{mL}$, respectively. The comet rate (comet\%), length of tail, the percentage in DNA tail (TDNA\%) and olive tail moment (OTM) induced by $\mathrm{SiO}_{2}$ nanoparticles were significantly increased in comparison with control and microscale $\mathrm{SiO}_{2}$ at $500 \mu \mathrm{g} / \mathrm{mL}$. 500 $\mu \mathrm{g} / \mathrm{mL} \mathrm{SiO}{ }_{2}$ nanoparticles and microscale $\mathrm{SiO}_{2}$ caused a significant increase in apoptosis rate, decreased proliferation index and increased cell proportions in $\mathrm{G}_{0} / \mathrm{G}_{1}$ phases by contrast to the negative control ( $P$ $<0.05$ ). This indicates that $\mathrm{SiO}_{2}$ nanoparticles are more cytotoxic than microscale $\mathrm{SiO}_{2}$ particles; they induce DNA injury, increase apoptosis, and decrease the proliferation index in RAW264.7 cells. DNA injury and apoptosis may be involved in reducing cell proliferation.

Key words: $\mathrm{SiO}_{2}$ nanoparticles; RAW 264.7 cells; DNA damage; Cytotoxicity; Apoptosis; Cell cycle

\section{INTRODUCTION}

In recent years, the rapid development of nanotechnology has resulted in numerous engineered nanoparticles (ENPs). The widespread application of ENPs in various fields will increase ENP exposure. As a non-metal oxide and an important nanomaterial, silica $\left(\mathrm{SiO}_{2}\right)$ nanoparticles have received much attention. In order to prevent the potential hazards of exposure to $\mathrm{SiO}_{2}$ nanoparticles, their toxic effects have been summarized from the environmental (Kim et al., 2012), health (Napierska et al., 2010), toxicological (Freese et al., 2014, van der Zande et al., 2014), and scientific respects (Nel et al., 2006). Experiments both in vivo and vitro have been conducted to confirm the underlying toxic actions of $\mathrm{SiO}_{2}$ nanoparticles. $\mathrm{SiO}_{2}$ nanoparticles caused dose-dependent cell toxicity in cultivated human broncho-alveolar carcinoma-derived cells (A549) and increased oxidative stress (Lin et al., 2006), release of various cytokines from RAW 264.7 macrophages (Park et al., 2011a), decreased fibroblast viability at high doses (Chang et al., 2007), and lung fibrosis in Wistar rats (Chen et al., 2004). Cellular and genetic toxicity of ultrafine crystalline $\mathrm{SiO}_{2}$ (diameter $<100 \mathrm{~nm}$ ) particles were found to in cultivated human cells (Wang et al., 2007). In addition, a study in mice indicated that $\mathrm{SiO}_{2}$ nanoparticles are non-poisonous and can therefore be applied to in vivo (Xue et al., 2006). Amorphous $\mathrm{SiO}_{2}$ nanoparticles activated no cell toxicity or genetic toxicity effects and caused no morphologic diversification, suggesting that they likely were a valuable constituent in industrial applications (Uboldi et al., 2012). These incongruent results need to be dealt with.

Inhalation of crystalline $\mathrm{SiO}_{2}$ leads to chronic obstructive lung disease, pneumosilicosis, even lung carcinoma (Hnizdo and Vallyathan, 2003; Schottenfeld and Beebe-Dimmer, 2006). A number of potential genotoxic effects of crystalline $\mathrm{SiO}_{2}$ have also been reported in literature. Crystalline $\mathrm{SiO}_{2}$ exposure under experimental conditions caused genetic injury, or other transforms. Study results demonstrated that crystalline $\mathrm{SiO}_{2}$ could be involved in carcinogenesis (Nagalakshmi et al., 1995; Ishihara et al., 2002; Başaran et al., 2003). This underlying complexity is confirmed by outcome of the alkaline comet assay, which lead augment of DNA injury of workers' peripheral lymphocytes in foundry and pottery, and this harmful affect could be attribute to silica exposure (Ishihara et al., 2002). Moreover, $\mathrm{SiO}_{2}$ nanoparticles of less than $100 \mathrm{~nm}$ may diffuse through cell membranes and bind to DNA, then directly interact with hereditary material. This is perhaps another route for $\mathrm{SiO}_{2}$ nanoparticles

Genetics and Molecular Research 15 (3): gmr.15039005 
to induce mutations and be conductive to carcinogenic effect. There is paucity data regarding genotoxicity for $\mathrm{SiO}_{2}$ nanoparticles. Park MV et al. used the micronucleus (MN) assay to report that $80 \mathrm{~nm} \mathrm{SiO}$ nanoparticles caused chromosome distortions in 3T3-L1 mouse inoblasts, and that the $\mathrm{SiO}_{2}$ nanoparticles of size at 30 and $80 \mathrm{~nm}$ elicited mutagenesis of embryonal inoblasts carried the lacZ reporter gene by mouse (Park et al., 2011b). In HT29, HaCat, and A549 cells, DNA injury determined using the comet assay was evidently observed at $\mathrm{SiO}_{2}$ nanoparticle (14 nm diameter) dosages of 0.1-10 $\mu \mathrm{g} / \mathrm{mL}$ (Mu et al., 2012). In contrast, amorphous $\mathrm{SiO}_{2}$ nanoparticles caused no morphologic change in Balb/3T3 cells and result in no genetic toxicity, as separately revealed by the Cell Transformation Test and the MN assay (Uboldi et al., 2012). Guichard et al discovered that no significance of DNA injury caused by artificial amorphous $\mathrm{SiO}_{2}$ nanoparticle as evaluated applying the red blood cell MN test and the normative and Fpg-reformed SCEG on cells derived from broncho-alveolar lavage fluid (BALF), the lungs, sanguis, splenic organ, hepar, keest, and kidneys in rats treated with intratracheal instillations at 3,24 and $48 \mathrm{~h}$ (Guichard et al., 2015). No obvious augment in DNA injury was noted in several tissues (sanguis, splenic organ from femur, hepar, keest, kidney, duodenum, and colon) of amorphous $\mathrm{SiO}_{2}$ nanoparticles -exposed rats following oral exposure for $3 \mathrm{~d}$ using the alkaline and Fpg-reformed comet assays (Tarantini et al., 2015). Thus, the potential genotoxicity of $\mathrm{SiO}_{2}$ nanoparticles need more clarification.

Our purpose was to probe whether $\mathrm{SiO}_{2}$ nanoparticles cause cellular and genetic toxic effects in RAW264.7 cells in vitro. The study involves testing for cytotoxicity, DNA strand breakages, apoptosis, and cell cycle in nanoparticle treated cells.

\section{MATERIAL AND METHODS}

\section{Preparation of $\mathrm{SiO}_{2}$ nanoparticles and microscale $\mathrm{SiO}_{2}$ particle suspensions}

$\mathrm{SiO}_{2}$ powders containing particles of two sizes were used in the cytotoxicity experiments. $\mathrm{SiO}_{2}$ nanoparticles (SP1, $20 \mathrm{~nm}$ ) were provided by Zhejiang Hongsheng Material Technology Co., Ltd. (Zhejiang, China). The $\mathrm{SiO}_{2}$ and the hydroxy group content of the $\mathrm{SiO}_{2}$ nanoparticles was greater than 99.5 and $45 \%$ respectively. The surface area of the $\mathrm{SiO}_{2}$ nanoparticles was $640 \pm 50 \mathrm{~m}^{2} / \mathrm{g}$ (as provided by the production company). The microscale $\mathrm{SiO}_{2}$ powder was obtained from Sigma-Aldrich (cat. No. 5631, USA), in which approximately $80 \%$ of the $\mathrm{SiO}_{2}$ particles were between 1-5 $\mu \mathrm{m}$ in diameter, and the purity was $99 \%$ according to safety data sheet. The materials were characterized using Hitachi S4800 scan electron microscopy (SEM, Figure 1A), FEI Tecnai G2 F20 S-Twin transmission electron microscopy (TEM, Figure 1B) and PANalytical X' Pert Pro X-ray diffractometer (XRD, Figure 2).
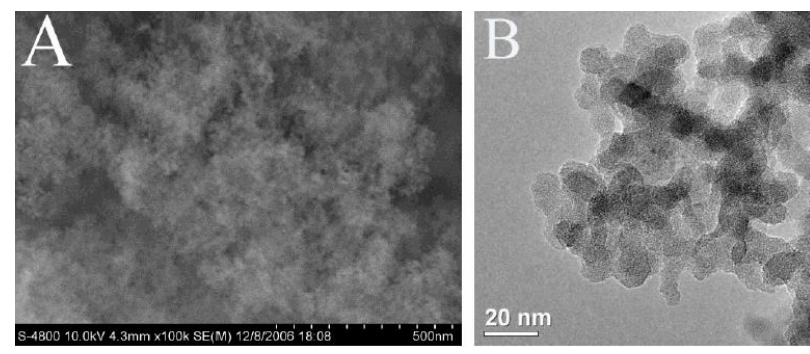

Figure 1. SEM and TEM image of $\mathrm{SiO}_{2}$ nanoparticles. A. SEM. B. TEM (x10 $)$.

Genetics and Molecular Research 15 (3): gmr.15039005 

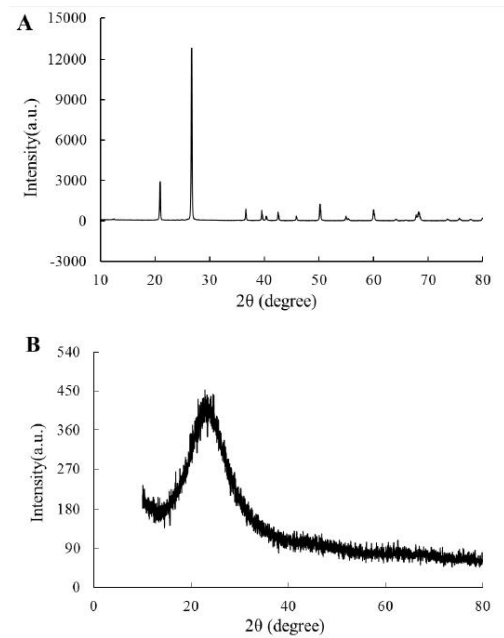

Figure 2. X-ray diffractometer (XRD) illustrations of $\mathrm{SiO}_{2}$ nanoparticles and microscale $\mathrm{SiO}_{2}$. $\mathbf{A} \cdot \mathrm{SiO}_{2}$ nanoparticles. B. Microscale $\mathrm{SiO}_{2}$.

Sterilized $\mathrm{SiO}_{2}$ nanoparticles and microscale $\mathrm{SiO}_{2}$ particles were suspended in cell cultivation media and were dispersed by ultrasonic vibration for $15 \mathrm{~min}$. The particle dispersions were freshly prepared for each experiment, thinned to diverse concentrations, and promptly applied to RAW264.7 cells in order to avoid the aggregation of particles.

\section{Cell line and cell culture}

RAW264.7 cells were achieved from the Shanghai Institute of Biochemistry and Shanghai Institute of Cell Biology, Chinese Academy Sciences. The cells were planted in DMEM addition with $10 \%(\mathrm{v} / \mathrm{v})$ blood serum of newborn calf, $1.5 \mathrm{mM} \mathrm{L}$-glutamine, 100 $\mathrm{U} / \mathrm{mL}$ penicillin, and $100 \mu \mathrm{g} / \mathrm{mL}$ streptomycin, and sustained at $37^{\circ} \mathrm{C}$ in a humidified $5 \%$ $\mathrm{CO}_{2}$ incubator. All cell culture materials were products of Gibco (USA), unless otherwise indicated. Exponential growth cells were applied for all the experiments.

\section{Assessment of cytotoxicity}

The latent cytotoxicity of the $\mathrm{SiO}_{2}$ particles was detected adopting the MTT test. Briefly, $200 \mu \mathrm{L}$ cell suspension containing $1 \times 10^{5}$ RAW264.7 cells was seeded into per well of a 96-well culture plate for $24 \mathrm{~h}$. The culture medium was then displaced with freshly dispersed particle suspension $(200 \mu \mathrm{L})$ containing $0,46.875,93.75,187.5$, $375,750,1500,3000,6000,12000$, and $24000 \mu \mathrm{g} / \mathrm{mL} \mathrm{SiO}$ nanoparticles and 62.5, 125, $250,500,1000,2000,4000,8000,16000$ and $32000 \mu \mathrm{g} / \mathrm{mL}$ microscale $\mathrm{SiO}_{2}$ prepared in culture medium ( 5 replicates for each particle concentration). The cells were cultivated with the particles for $24 \mathrm{~h}$ and the waste culture medium was then drawn from the cells. Subsequently, $100 \mu \mathrm{L}$ treatment medium including $5 \mathrm{mg} / \mathrm{mL}$ 3-(4,5-dimethylthiazol-2-yl)2,5-diphenyl tetrazolium bromide (MTT, Sigma, USA) in $0.9 \% \mathrm{NaCl}$ liquor was dropped to per well and the cells were cultivated for an extra $3 \mathrm{~h}$. The medium was then extract 
from the wells, followed by supplement to $150 \mu \mathrm{L}$ dimethyl sulfoxide (DMSO, Sigma, USA) and shaking the plate on an orbital shaker at room temperature for $15 \mathrm{~min}$. Finally, the optical density (OD)/absorbancy of per well was detected at $570 \mathrm{~nm}$ on the microplate reader (MRX, Dynex Technologies Company, USA). The cell viability rate (\%) compared to control wells including cell culture medium with no particles as a vehicle was counted as (A) ${ }_{\text {test }} /(\mathrm{A})_{\text {control }} \times 100 \%$, where (A) ${ }_{\text {test }}$ is the absorbancy of particles treated wells and (A) ${ }_{\text {control }}$ is the absorbancy of the untreated wells for $24 \mathrm{~h}$. The inhibitory concentration $50 \%\left(\mathrm{IC}_{50}\right)$ values were calculated utilizing the Bliss method. According to the curve of cell inhibition, cell viability was greater than $85 \%$ after cells exposure to $500 \mu \mathrm{g} / \mathrm{mL} \mathrm{SiO}_{2}$ nanoparticles and microscale $\mathrm{SiO}_{2}$ for $24 \mathrm{~h}$. Thus, the doses of 500,125 , and $31.25 \mu \mathrm{g} / \mathrm{mL}$ were chosen for cell treatment in the comet, apoptosis, and cell cycle assay.

\section{SCGE assay (Comet assay)}

SCGE assay, commonly known as comet assay was performed in accordance with the recommended guidelines (Singh et al., 1988; Olive et al., 1990; Tice et al., 2000). Cell were cultured in flasks for $24 \mathrm{~h}$ and grown to a concentration of $2 \times 10^{5}$ cells $/ \mathrm{mL}$, then separately dropped 500,125 , and $31.25 \mu \mathrm{g} / \mathrm{mL} \mathrm{SiO}_{2}$ nanoparticles and $500 \mu \mathrm{g} / \mathrm{mL}$ microscale $\mathrm{SiO}_{2}$ into flasks for an extra $24 \mathrm{~h}$. The cells of washing, centrifugal separation (at $78 \mathrm{~g}$ for $5 \mathrm{~min}$ ) twice with prechilled PBS (free of $\mathrm{Mg}^{2+}$ and $\mathrm{Ca}^{2+}$ were then gathered and re-suspended in PBS. Negative control was untreated cells.

$100 \mu \mathrm{L} 0.8 \%$ normal-melting agarose (NMA, Sigma, USA) in PBS at $50^{\circ} \mathrm{C}$ was dropped on a frosted slide. A coverslip was promptly overlapped, and solidified at $4^{\circ} \mathrm{C}$ for $5 \mathrm{~min}$, then taken away coverslip. $50 \mu \mathrm{L}$ cell suspension at $10^{5}$ cells $/ \mathrm{mL}$ and $300 \mu \mathrm{L} 0.7 \%$ low melting agarose (LMA, Sigma, USA) in PBS at $37^{\circ} \mathrm{C}$ were blended and $75 \mu \mathrm{L}$ aliquot of a mixture were pipetted onto the slides. A coverslip was layered on the slide again and the layer was solidified in dark at $4^{\circ} \mathrm{C}$ for $5 \mathrm{~min}$. The coverslips were withdrawn and the slides overlapped on layers were submerged within lately formulated pre-chilled lysing liquor $(2.5 \mathrm{M} \mathrm{NaCl}, 100 \mathrm{mM} \mathrm{Na}$ EDTA, $10 \mathrm{mM}$ Tris, $1 \%$ sodium lauroyl sarcosine with $1 \%$ Triton $\mathrm{X}-100$ and $10 \%$ DMSO joined freshly, $\mathrm{pH}=10$ ) in a well-closed light for $1 \mathrm{~h}$ at $4^{\circ} \mathrm{C}$. The slides were put into a flat gel electrophoresis chamber imbued with new alkaline buffer $\left(1 \mathrm{mM} \mathrm{Na}{ }_{2}\right.$ EDTA and $\left.300 \mathrm{mM} \mathrm{NaOH}, \mathrm{pH}=13\right)$ for $40 \mathrm{~min}$ at $4^{\circ} \mathrm{C}$ to denaturalize and spread DNA, and express alkaline-labile sites. Electrophoresis was performed in the same buffer at $20 \mathrm{~V}$ and $200 \mathrm{~mA}$ for $40 \mathrm{~min}$ to migrate the anodic destroyed DNA or DNA fraction. All above steps were in progress under dim light conditions to avoid extra DNA injury. The slides were then cleaned thrice with $0.4 \mathrm{M}$ Tris- $\mathrm{HCl}$ for $15 \mathrm{~min}$ and tapped on a filter paper to eliminate excrescent liquor, and dyed with $100 \mu \mathrm{L}$ DNA-binding dye PI (50 $\mu \mathrm{g} / \mathrm{mL}$ ). The slides were evaluated under a fluorescence microscope (BX-41, Olympus) at 200X enlargement factor adopting a blue filter $(450-490 \mathrm{~nm})$, and taken a picture by means of a digital camera (Olympus). Intact cells showed as a nucleoid whereas DNA injured cells appeared as a comet. At the fewest 30 randomly chosen cells of DNA injury were assessed from per specimen and examined by the comet assay software project (CASP) software. A slide with layered unhandled cells was exposed to an ultraviolet lamp $(18 \mathrm{~W}, 40 \mathrm{~cm})$ for $6 \mathrm{~min}$ and regard as the positive control. The ratio of comet (comet\%), the tail length (TL), the percentage in DNA tail (TDNA\%), and the olive tail moment (OTM) were regard as DNA injury indicators.

Genetics and Molecular Research 15 (3): gmr.15039005 


\section{Apoptosis assessment by flow cytometry (FCM)}

Apoptosis in RAW264.7 cells were detected by double dyeing for Annexin V and propidium iodide (PI). The detection kit contains Annexin V connected to fluorescein isothiocyanate (FITC) (Nanjing Keygen Biotech. Co. Ltd., China). After treatment as described for the comet assay, RAW264.7 cells were cleaned tow time with cold PBS solution. After centrifugating at $78 \mathrm{~g}$ for $5 \mathrm{~min}$, the resuspension of cell pills were performed in buffer solution at $10^{6}$ cells $/ \mathrm{mL}$. $100 \mu \mathrm{L}$ cells suspension was moved into a cuvette and dyed with 5 $\mu \mathrm{L}$ Annexin V-FITC and $5 \mu \mathrm{L}$ PI liquor for 15 min away from light at room temperature. The mixture of suspension was diluted by $400 \mu \mathrm{L}$ buffer solution. The fluorescent magnitude of Annexin V-FITC and PI was counted by a FCM (Cell Lab Quanta SC, Coulter, USA) and the appropriate software. At lowest 10,000 cells from per specimen were assessed and the proportion of positive cells was detected. A drop of cell suspension double dyed by Annexin V-FITC and PI was taken on a glass slide. Then the pattern of apoptotic cells was watched under a fluorescence microscope (BX-41, Olympus).

\section{Cell cycle assay by FCM}

The alterations in cell cycle kinetics induced by the $\mathrm{SiO}_{2}$ particulates were examined with flow cytometry following to the directions of the cell cycle kit (Nanjing Keygen Biotech. Co., Ltd., China). At $24 \mathrm{~h}$ after addition of particles as in the comet assay, cells were gathered by trypsinization, cleaned with pre-cold PBS, and solidified overnight in pre-cold $70 \%$ ethanol at $4^{\circ} \mathrm{C}$. Solidified cells were then cleaned twice with PBS and deal with $100 \mu \mathrm{L}$ RNaseA (1 $\mathrm{mg} / \mathrm{mL}$ ) for $30 \mathrm{~min}$ at room temperature away from light. Lastly, the cells were dyed with 50 $\mu \mathrm{L}$ PI at $1 \mathrm{mg} / \mathrm{mL}$, diluted in PBS to a terminal capacity of $0.5 \mathrm{~mL}$, and place for $40 \mathrm{~min}$ in ice bath without light. Cell cycle distribution was analyzed using a FCM. Approximately $1 \times 10^{6}$ cells were measured for per specimen. The distribution percentage rate of cells in the $G_{0} / G_{1}, S$, and $\mathrm{G}_{2} / \mathrm{M}$ stages in cell cycle was measured by computer analysis system. Proliferation index was computed as following formulae: Proliferation index $=\left(S+G_{2} / M\right) /\left(G_{0} / G_{1}+S+G_{2} / M\right)$.

\section{Statistical methods}

All experiments were replicated at any rate thrice separate time. The data are showed as mean $\pm \mathrm{SEM}$, and significance of difference was carried out applying either the Dunnetts $t$-test or the Student $t$-test by the SAS software, version 8.2. Level of significance was a P value of 0.05 .

\section{RESULTS}

\section{Cell viability after nanoparticle treatment}

MTT cell multiplication assay was used to examine cellular toxicity caused by $\mathrm{SiO}_{2}$ nanoparticles in this study. The surviving cells transformed the tetrazolium constituent of the compound into a formazan production with assimilation at $570 \mathrm{~nm}$ (Mosmann, 1983). The absorbancy was in proportion to the quantity of survival cells. Cell viability was detected against the untreated cells (Figure 3). The cell viability was reduced with increasing concentration of $\mathrm{SiO}_{2}$ nanoparticles and microscale $\mathrm{SiO}_{2}$. $\mathrm{SiO}_{2}$ nanoparticles at a dosage of $100 \mu \mathrm{g} / \mathrm{mL}$ reduced

Genetics and Molecular Research 15 (3): gmr.15039005 
viability but not significantly $(80 \%, 24 \mathrm{~h})$. However, $\mathrm{SiO}_{2}$ nanoparticles were at high concentration of $750 \mu \mathrm{g} / \mathrm{mL}$, cell survival rate was substantially decreased to $50 \%(24 \mathrm{~h})$. The $\mathrm{IC}_{50}$ of $\mathrm{SiO}_{2}$ nanoparticles and microscale $\mathrm{SiO}_{2}$ treated for $24 \mathrm{~h}$ was 5080 and $16690 \mu \mathrm{g} / \mathrm{mL}$, respectively.

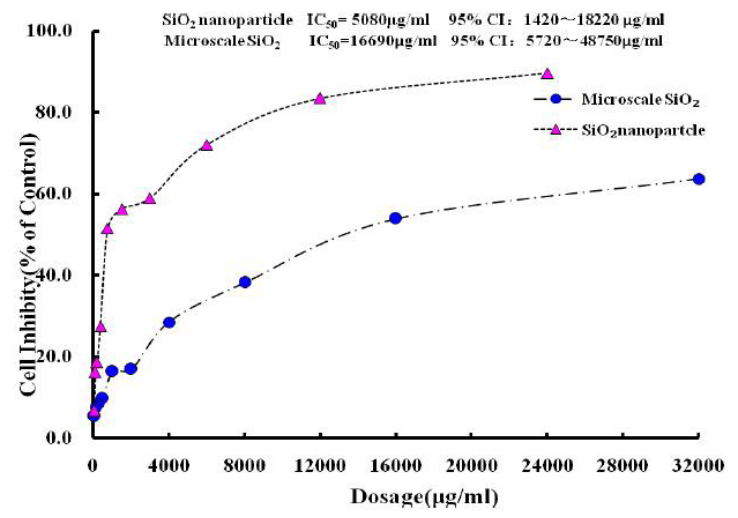

Figure 3. Cytotoxic effects of $\mathrm{SiO}_{2}$ nanoparticles and microscale $\mathrm{SiO}_{2}$ in RAW264.7 cells.

\section{Examination of single strand DNA breakages}

Single strand DNA breakages were estimated using entire cells as objectives in SCEG. In presence of single strand DNA breakages, comet tails of cells would be observed on the fluorescence pictures (Figure 4). The comet $\%$, comet TL, TDNA\%, and OTM were regarded as in proportion to the quantity of DNA injury experienced by the cells. Due to the usual series of cell administrations in SCEG, some factitious DNA injury was always observed. In the negative control, the comet $\%$, TL, TDNA $\%$, and OTM values were $5.02 \pm 0.38,5.51 \pm 0.89,0.91 \pm 0.15$, and $2.58 \pm 0.78$, respectively (Table 1). Cells treated by $\mathrm{SiO}_{2}$ nanoparticles for $24 \mathrm{~h}$ displayed a significant increase in TL, TDNA \%, and OTM values comparing to the untreated cells starting from the dose of $31.25 \mu \mathrm{g} / \mathrm{mL}(\mathrm{P}<0.05)$. Comet proportion in cells treated by $\mathrm{SiO}_{2}$ nanoparticles with respect to the untreated cells after $24 \mathrm{~h}$ was found to increase significantly at doses of 125 and $500 \mu \mathrm{g} / \mathrm{mL}(\mathrm{P}<0.05)$. After $24 \mathrm{~h}$ of exposure to microscale $\mathrm{SiO}_{2}(500 \mu \mathrm{g} / \mathrm{mL})$, statistically significant amounts of DNA lesion indicators were observed $(\mathrm{P}<0.05)$ contrast to unexposed cells, and the effects of microscale $\mathrm{SiO}_{2}$ in RAW264.7 cells were much stronger than those of $\mathrm{SiO}_{2}$ nanoparticles at a concentration of $500 \mu \mathrm{g} / \mathrm{mL}(\mathrm{P}<0.05)$.

\section{Quantitative determination of apoptosis by FCM}

Apoptosis in RAW264.7 cells following treatment to $\mathrm{SiO}_{2}$ nanoparticles was determined adopting the FITC-labeled Annexin-V assay, in which phosphatidylserine (PS) externalization is a widely accepted marker of early apoptosis, whereas late apoptotic and necrotic cells show high absorption of PI and low combining of Annexin-V (Figure 5). The apoptotic cell rates were determined by FCM. The negative control showed $0.3 \pm 0.1 \%$ of apoptosis rate (Figure 6 ). With a raise in $\mathrm{SiO}_{2}$ nanoparticle dosage, a general trend towards elevation in apoptosis rate was perceived, and a significant difference was observed at dosages of 125 and $500 \mu \mathrm{g} / \mathrm{mL}$ compared to untreated cells based on the Dunnetts $t$-test $(\mathrm{P}<0.05)$. Obvious difference was not observed for apoptosis rate between $\mathrm{SiO}_{2}$ nanoparticles and microscale $\mathrm{SiO}_{2}$ at dosage of $500 \mu \mathrm{g} / \mathrm{mL}$.

Genetics and Molecular Research 15 (3): gmr.15039005 

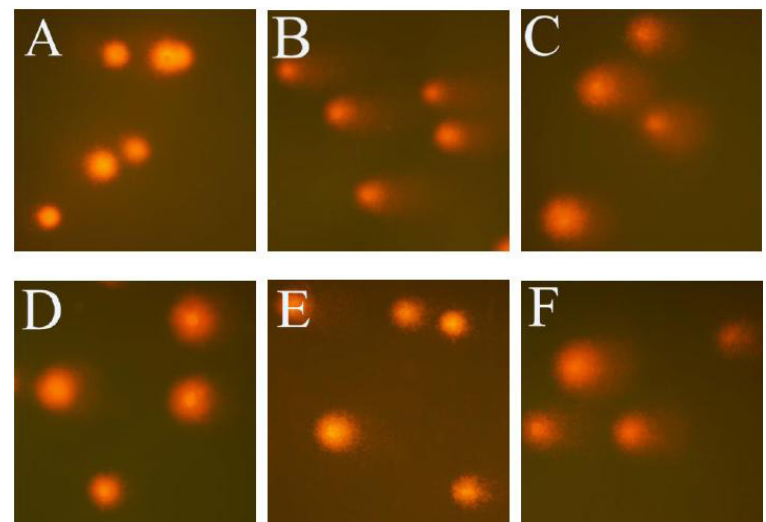

Figure 4. A fluorescence image of DNA strand breakages as observed by the SCEG. A. Negative control. B. Positive control. C. $500 \mu \mathrm{g} / \mathrm{mL}$ microscale $\mathrm{SiO}_{2}$ particles. D. $31.25 \mu \mathrm{g} / \mathrm{mL} \mathrm{SiO}_{2}$ nanoparticles. E. $125 \mu \mathrm{g} / \mathrm{mL} \mathrm{SiO}_{2}$ nanoparticles. F. $500 \mu \mathrm{g} / \mathrm{mL} \mathrm{SiO}_{2}$ nanoparticles.

Table 1. DNA damage effects in RAW264.7 cells induced by $\mathrm{SiO}_{2}$ nanoparticles (means $\pm \mathrm{SE}$ ).

\begin{tabular}{l|c|c|c|c|c}
\hline Groups & Dosage $(\mu \mathrm{g} / \mathrm{mL})$ & Comet $(\%)(\mathrm{N}=200)$ & Tail length $(\mathrm{N}=30)$ & TDNA $(\%)(\mathrm{N}=30)$ & OTM $(\mathrm{N}=30)$ \\
\hline Negative control & & $5.02 \pm 0.38$ & $5.51 \pm 0.89$ & $0.91 \pm 0.15$ & $2.58 \pm 0.78$ \\
\hline Positive control & & $99.57 \pm 0.75$ & $190.13 \pm 50.43$ & $21.01 \pm 7.32$ & $42.85 \pm 17.55$ \\
\hline Microscale $\mathrm{SiO}_{2}$ & 500 & $55.41 \pm 10.49^{*}$ & $203.57 \pm 44.66^{*}$ & $21.05 \pm 9.58^{*}$ & $45.33 \pm 22.18^{*}$ \\
\hline $\mathrm{SiO}_{2}$ nanoparticles & 31.25 & $15.57 \pm 4.44$ & $136.03 \pm 80.81^{*}$ & $8.63 \pm 8.39^{*}$ & $15.38 \pm 15.12^{*}$ \\
\cline { 2 - 7 } & 125 & $19.11 \pm 4.66^{*}$ & $161.20 \pm 90.18^{*}$ & $10.48 \pm 7.38^{*}$ & $21.13 \pm 18.48^{*}$ \\
\cline { 2 - 6 } & 500 & $26.43 \pm 4.17^{* *}$ & $183.49 \pm 63.27^{*}$ & $14.14 \pm 8.45^{* \#}$ & $29.13 \pm 20.62^{* \#}$ \\
\hline
\end{tabular}

The results are reported as means $\pm \mathrm{SD}$. Significance is shown by: $* \mathrm{P}<0.05$ versus negative untreated cells; ${ }^{\#} \mathrm{P}<$ 0.05 , contrast to cells treated by the same concentration of microscale $\mathrm{SiO}_{2}$.
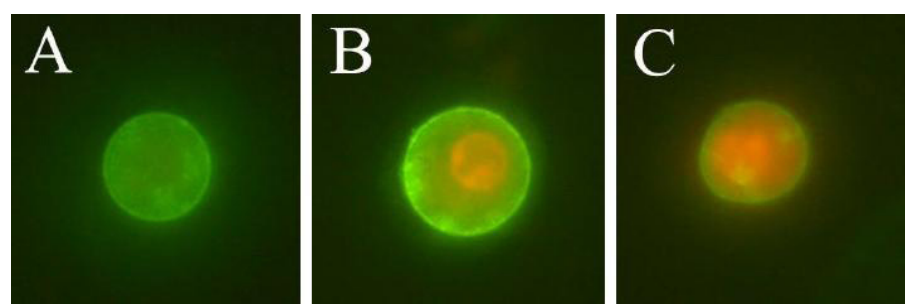

Figure 5. Fluorescence photomicrographs of $\mathrm{SiO}_{2}$ nanoparticle-induced apoptosis in RAW264.7 cells double dyed by Annexin V-FITC and PI. A. Early apoptotic cell. B. Late apoptotic cell. C. Necrotic cell. 400X.

\section{Study of cell cycle distribution}

In order to confirm whether the exposure of RAW264.7 cells to $\mathrm{SiO}_{2}$ nanoparticles resulted in altered in cell cycle distribution, we performed FCM using PI dyeing. These studies revealed that $\mathrm{SiO}_{2}$ nanoparticles at $125 \mu \mathrm{g} / \mathrm{mL}$ caused significant decrease in the proliferation index and increased the cell proportions in the $G_{0} / G_{1}$ phase $(P<0.05)$. Exposure to higher concentrations $(500 \mu \mathrm{g} / \mathrm{mL})$ of $\mathrm{SiO}_{2}$ nanoparticles and microscale $\mathrm{SiO}_{2}$ resulted in decreased cell proliferation index and elevation $(P<0.05)$ of cells in $G_{0} / G_{1}$ and $S$ stages contrasted the negative untreated cell (Table 2). No changes in cell cycle distribution were observed after the 
addition of $31.25 \mu \mathrm{g} / \mathrm{mL} \mathrm{SiO}_{2}$ nanoparticles to the cultured cells. The changes in proliferation index and the per centum of cells in the $\mathrm{G}_{0} / \mathrm{G}_{1}$ and $\mathrm{S}$ stages caused by $\mathrm{SiO}_{2}$ nanoparticles and microscale $\mathrm{SiO}_{2}$ at a dosage of $500 \mu \mathrm{g} / \mathrm{mL}$ were not significantly different.
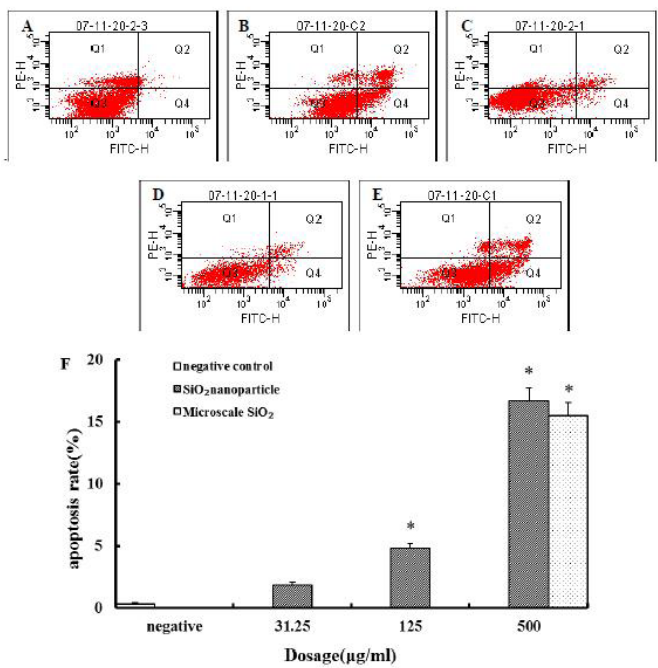

Figure 6. Analysis of $\mathrm{SiO}_{2}$ nanoparticle-induced apoptosis in RAW264.7 cells double dyed by Annexin V-FITC and PI with FCM. A. Negative control. B. $500 \mu \mathrm{g} / \mathrm{mL}$ microscale $\mathrm{SiO}_{2}$ particles. C. $31.25 \mu \mathrm{g} / \mathrm{mL} \mathrm{SiO}$ nanoparticles. D. $125 \mu \mathrm{g} / \mathrm{mL} \mathrm{SiO}_{2}$ nanoparticles. E. $500 \mu \mathrm{g} / \mathrm{mL} \mathrm{SiO}_{2}$ nanoparticles. F. Apoptosis rate of RAW264.7 cells. Significance presented by: $* \mathrm{P}<0.05$ versus negative control cells.

Table 2. Changes in the cell cycle of RAW264.7 cells induced by $\mathrm{SiO}_{2}$ nanoparticles (means $\pm \mathrm{s}$ ).

\begin{tabular}{l|c|c|c|c|c}
\hline \multirow{2}{*}{ Groups } & Dosage $(\mu \mathrm{g} / \mathrm{mL})$ & \multicolumn{3}{|c|}{ Cell cycle distribution $(\%)$} & \multirow{2}{*}{ PI } \\
\cline { 2 - 6 } & & $\mathrm{G}_{0} / \mathrm{G}_{1}$ & $\mathrm{~S}$ & $\mathrm{G}_{2} / \mathrm{M}$ & \\
\hline Negative control & 0 & $49.08 \pm 2.81$ & $40.62 \pm 2.55$ & $9.97 \pm 1.05$ & $50.92 \pm 2.31$ \\
\hline Microscale $\mathrm{SiO}_{2}$ & 500 & $57.83 \pm 2.89^{*}$ & $33.73 \pm 2.88^{*}$ & $8.44 \pm 1.16$ & $42.17 \pm 2.89^{*}$ \\
\hline $\mathrm{SiO}_{2}$ nanoparticles & 31.25 & $51.90 \pm 2.91$ & $40.29 \pm 2.24$ & $7.81 \pm 0.95$ & $48.10 \pm 2.91$ \\
\cline { 2 - 6 } & 125 & $57.17 \pm 2.40^{*}$ & $34.37 \pm 2.35$ & $8.46 \pm 1.87$ & $42.83 \pm 2.40^{*}$ \\
\cline { 2 - 6 } & 500 & $60.07 \pm 3.43^{*}$ & $31.92 \pm 3.06^{*}$ & $8.01 \pm 1.23$ & $39.93 \pm 3.43^{*}$ \\
\hline
\end{tabular}

The results are reported as means $\pm \mathrm{SD}$. Significance is shown by: $* \mathrm{P}<0.05$, contrast to negative untreated cells.

\section{DISCUSSION}

Our study manifested that $\mathrm{SiO}_{2}$ nanoparticles lead a dose-related augment in cell toxicity, as detected by the MTT test, wherein the $\mathrm{IC}_{50}$ induced by $\mathrm{SiO}_{2}$ nanoparticles was less than that of microscale $\mathrm{SiO}_{2}$. It is agreement with former reports demonstrating that $\mathrm{SiO}_{2}$ nanoparticles showed greater cell toxicity than crystalline $\mathrm{SiO}_{2}$ in at the dosage range of 50-100 $\mu \mathrm{g} / \mathrm{mL}$ (Lin et al., 2006). In an in vivo research, Warheit et al. also discovered that $12 \mathrm{~nm} \mathrm{SiO}{ }_{2}$ nanoparticles generated more serious inflammation reaction in rats' lung tissue than diameter of $1.6 \mu \mathrm{m}$ Min-U-Sil quartz particles behind intracheal instillation particles at dosage of 1 or 5 $\mathrm{mg} / \mathrm{kg}$. But in an independent test of the identical investigation, the authors discovered that 50 $\mathrm{nm} \mathrm{SiO}{ }_{2}$ nanoparticles caused slight inflammatory potency in comparison of Min-U-Sil quartz 
particles (Warheit et al., 2007). Chen et al. described that there was Stage I of silicotic nodules in lung tissue of rats after 2 months instillation of $\mathrm{SiO}_{2}$ nanoparticles. However, there mainly were Stage II and III of silicotic nodules in rats' lung tissue after instillation of microscale $\mathrm{SiO}_{2}$. The experiment indicated that the fibrogenic effect caused by $\mathrm{SiO}_{2}$ nanoparticles was probably gentler than that of microscale $\mathrm{SiO}_{2}$ in rats, possibly leading from the diffusion and translocation of nanoparticles due to their tiny particle size in comparison to micro-sized particles (Chen et al., 2004).

The carcinogenic effect of long-term contact with silica has been principally certified in vivo investigations on rats. A separate trials on rats administrated by inhaling and intratracheally instillating crystalline $\mathrm{SiO}_{2}$ with respirable dimension, displayed premutagenic 8-oxo-7,8dihydro-2'-deoxyguanosine (8-OHdG) DNA lesions (Yamano et al., 1995; Nehls et al., 1997), occurrence of pulmonary tissue lesions (Johnston et al., 2000; Albrecht et al., 2005), and development of pulmonary carcinomas (Blanco et al., 2004). Phymatoid pulmonary damage has also been surveyed in rats' long-term post-exposure to crystalline $\mathrm{SiO}_{2}$ at low dosages of $1 \mathrm{mg} / \mathrm{m}^{3}$ (Muhle et al., 1995). Crystalline $\mathrm{SiO}_{2}$ (quartz and cristobalite) was classified as a human blastomogen in 1997 by the International Agency for Research on Cancer (IARC) on the basis of evidence gained from two sides of animal experimental models and population epidemiological investigations. Several research groups have also demonstrated DNA injury induction by crystalline $\mathrm{SiO}_{2}$ in vitro. Quartz elicits DNA injury in rat and human alveolar epithelial cells indicating that these effects are initiated by the hydroxyl radical-producing features of these particles (Schins et al., 2002). As an initial event, oxidative injury at both level of DNA and membrane, and a popularization of genetic toxicity and cell toxicity effects with prolongation of exposure time and increase of exposure dosages, supports and explains the pulmonary inflammation and pneumoconiosis (caused by oxidative stress) as a prior effect perceived in vivo and in occupational populations of exposure to quartz with pulmonary fibrogenic and carcinogenic effects (caused by forceful membrane translations, DNA strand breakages and cancer genes sensitization /inhibitor genes deactivation) as a posterior effect of delayed and enhanced exposure (Kipen and Laskin, 2005). Our results state clearly that the $\mathrm{SiO}_{2}$ nanoparticles lead a considerable number of DNA strand breakages as the microscale $\mathrm{SiO}_{2}$, with the DNA injury effect being weaker than microscale $\mathrm{SiO}_{2}$. This result seemed to be in conflict with the cytotoxic potential of these nanoparticles. It is commonly considered that a nanoparticle size is smaller, its cell toxicity is greater (Kipen and Laskin, 2005; Nel et al., 2006; Napierska et al., 2010). The variance in bioactivity is mainly correlated to the superficial properties and reaction that decide the toxic, oxidic, and genotoxic characteristics of the particles. The result may also be affected by an aggregation of $\mathrm{SiO}_{2}$ nanoparticles in DMEM complete media.

It is essential for maintaining genetic stability to own the wholeness of DNA sequences. DNA injury is related with apoptosis, tissue damage, and carcinogenicity (Cooke et al., 2003; Wu, 2005). MTT assays can only detect cell necrosis. Apoptosis and necrosis for two patterns of cell decease are outlined by explicitly recognizable morphologic benchmark (Leist et al., 1998). Several studies have shown that $\mathrm{SiO}_{2}$ induces apoptosis in A549 (Lim et al., 1999), MH-S (Thibodeau et al., 2004), and C141 cells (Wang et al., 2005). Since the chemical composition of $\mathrm{SiO}_{2}$ nanoparticles is the same as microscale $\mathrm{SiO}_{2}$ particles, we assume that $\mathrm{SiO}_{2}$ nanoparticle might affect apoptosis. Therefore, we used the FITC-labeled Annexin-V assay to differentiate apoptosis from necrosis in the RAW264.7 cell line. Our results indicated that $\mathrm{SiO}_{2}$ nanoparticles could induce noticeable apoptosis in RAW264.7

Genetics and Molecular Research 15 (3): gmr.15039005 
cells at 125 and $500 \mu \mathrm{g} / \mathrm{mL}$. To our knowledge, cytotoxicity caused by $\mathrm{SiO}_{2}$ nanoparticles are believed to occur prior apoptosis rather than prior cell necrosis, because cytotoxicity is taken form of the destruction of cell membranes from earliest incidents. In our experiments, as early apoptosis was observed, the cytomembrane was conserved in a majority of cells for a long time. However, as two aspects of cell death forms, namely apoptosis and necrosis, can happen synchronously or in a particular temporal or spatial relationship within the same apparatus. In addition, the proof indicates that identical receptor, signaling pathways can be involved in mechanisms of cell apoptosis or necrosis (Leist and Nicotera, 1997). In this study, we presume that DNA strand breakades and $\mathrm{SiO}_{2}$ nanoparticles-induced apoptosis resulted in toxicity. Therefore, the etiogenic role of the inherent apoptotic death passageway as a mechanization of $\mathrm{SiO}_{2}$ nanoparticles-induced apoptosis must be extensively investigated.

The study showed that the cell multiplication rate was closely related to apoptosis. Apoptosis resulted from retardarce of the cell multiplication cycle, and apoptosis often accompanied developmental blockage. Some consider that apoptosis only arises in the $G_{0} / G_{1}$ phase, but apoptosis can occur at all stages of the cell cycle. Apoptosis in different cell lines treated with distinct factors results in diverse cell cycle characteristics (Srivastava and Gupta, 2006). Our results, showing that $\mathrm{SiO}_{2}$ nanoparticles caused significant decrease in proliferation index, augment in ratio of cells in the $\mathrm{G}_{0} / \mathrm{G}_{1}$ phases, and absent significant difference between $\mathrm{SiO}_{2}$ nanoparticles and microscale $\mathrm{SiO}_{2}$ particles at the same dosage, suggest a role for DNA injury and apoptosis in these events. Crystalline $\mathrm{SiO}_{2}$ was observed to play the same role in mouse macrophage and human endotheliocytes (Thibodeau et al., 2003; Santarelli et al., 2004; Hu et al., 2007). Therefore, the cellular toxicity differences between nanoscale $\mathrm{SiO}_{2}$ and microscale $\mathrm{SiO}_{2}$ are required to be enucleated by the aid of more experiments and mechanistic studies. There are the complicacy and various properties of $\mathrm{SiO}_{2}$ nanoparticles and microscale $\mathrm{SiO}_{2}$ particles such as molecular structure, dimension, appearance, superficial activities, superficial treatment, and crystallinestate to affect their cytotoxicity. This study was only basis on dimension and crystallinestate probably to mislead if other variety is concerned. Thus, it is necessary to completely evaluate the effects of diverse particle peculiarities (Warheit et al., 2007).

\section{CONCLUSIONS}

As a result, above findings indicated that $\mathrm{SiO}_{2}$ nanoparticles have a cytotoxic effect on RAW264.7 cells. The $\mathrm{IC}_{50}$ induced by $\mathrm{SiO}_{2}$ nanoparticles is less than that of microscale $\mathrm{SiO}_{2}$. This discloses that $\mathrm{SiO}_{2}$ nanoparticles are more cytotoxic than microscale $\mathrm{SiO}_{2}$ particles. $\mathrm{SiO}_{2}$ nanoparticles induce DNA injury, increase apoptosis, decrease proliferation index, and increase the ratio of cells in the $\mathrm{G}_{0} / \mathrm{G}_{1}$ stage in RAW264.7 cells. We observed an exciting finding that the nanoparticles manifest to cause the same amount of genotoxicity as the microscale $\mathrm{SiO}_{2}$ particles, but the degree of DNA injury caused by $\mathrm{SiO}_{2}$ nanoparticles is less than that of microscale $\mathrm{SiO}_{2}$. The behavior is not same as customary cytotoxicity results. The study of DNA toxicological characteristics suggests that the genetic toxicity is less serious than cell injury. This perhaps suggests that there are toxic differences between $\mathrm{SiO}_{2}$ nanoparticles and microscale $\mathrm{SiO}_{2}$ particles. It is probable that cell decease can attribute to minor genome lesion but to major cytoplasmic organoids damage $(\mathrm{Wu}, 2005)$. Genetic toxicity is relevant to apoptosis triggered by a complex regulation (interconnected signal pathway mechanisms) (Ahmad et al., 2012; Ahamed, 2013), whereas cytotoxicity, for instance necrosis in our study, may be straight caused by cytomembrane injury. We conjecture that $\mathrm{SiO}_{2}$ nanoparticles may cause cells toxicity through

Genetics and Molecular Research 15 (3): gmr.15039005 
a specific pathway. DNA injury and apoptosis may also be involved in cell multiplication. Intensive studies are necessary to illuminate the exact mechanisms responsible for toxicity, DNA injury, and apoptosis caused by $\mathrm{SiO}_{2}$ nanoparticle in macrophages.

\section{ACKNOWLEDGMENTS}

Research supported by the National Natural Science Foundation of China (Grant \#84273046), the Major State Basic Research Development Program of China (973 Program, Grant \#2011CB933404), the Preventive Medicine Research Projects of Jiangsu Province (Grant \#Y2012039), and the Fundamental Research Funds for the Central Universities. We thank Mr. Junhao Chen (Department of Laboratory Science, the Affiliated Drum Tower Hospital of Nanjing University Medical College) for technical assistance with flow cytometry.

\section{REFERENCES}

Ahamed M (2013). Silica nanoparticles-induced cytotoxicity, oxidative stress and apoptosis in cultured A431 and A549 cells. Hum. Exp. Toxicol. 32: 186-195.http://dx.doi.org/10.1177/0960327112459206

Ahmad J, Ahamed M, Akhtar MJ, Alrokayan SA, et al. (2012). Apoptosis induction by silica nanoparticles mediated through reactive oxygen species in human liver cell line HepG2. Toxicol. Appl. Pharmacol. 259: 160-168. http:// dx.doi.org/10.1016/j.taap.2011.12.020

Albrecht C, Knaapen AM, Becker A, Höhr D, et al. (2005). The crucial role of particle surface reactivity in respirable quartz-induced reactive oxygen/nitrogen species formation and APE/Ref-1 induction in rat lung. Respir. Res. 6: 129144. http://dx.doi.org/10.1186/1465-9921-6-129

Başaran N, Shubair M, Undeğer U and Kars A (2003). Monitoring of DNA damage in foundry and pottery workers exposed to silica by the alkaline comet assay. Am. J. Ind. Med. 43: 602-610.http://dx.doi.org/10.1002/ajim.10222

Blanco D, Vicent S, Elizegi E, Pino I, et al. (2004). Altered expression of adhesion molecules and epithelial-mesenchymal transition in silica-induced rat lung carcinogenesis. Lab. Invest. 84: 999-1012. http://dx.doi.org/10.1038/ labinvest. 3700129

Chang JS, Chang KL, Hwang DF and Kong ZL (2007). In vitro cytotoxicitiy of silica nanoparticles at high concentrations strongly depends on the metabolic activity type of the cell line. Environ. Sci. Technol. 41: 2064-2068. http://dx.doi. org/10.1021/es062347t

Chen Y, Chen J, Dong J and Jin Y (2004). Comparing study of the effect of nanosized silicon dioxide and microsized silicon dioxide on fibrogenesis in rats. Toxicol. Ind. Health 20: 21-27.http://dx.doi.org/10.1191/0748233704th190oa

Cooke MS, Evans MD, Dizdaroglu M and Lunec J (2003). Oxidative DNA damage: mechanisms, mutation, and disease. FASEB J. 17: 1195-1214. http://dx.doi.org/10.1096/fj.02-0752rev

Freese C, Schreiner D, Anspach L, Bantz C, et al. (2014). In vitro investigation of silica nanoparticle uptake into human endothelial cells under physiological cyclic stretch. Part. Fibre Toxicol. 11: 68. http://dx.doi.org/10.1186/s12989014-0068-y

Guichard Y, Maire MA, Sébillaud S, Fontana C, et al. (2015). Genotoxicity of synthetic amorphous silica nanoparticles in rats following short-term exposure. Part 2: intratracheal instillation and intravenous injection. Environ. Mol. Mutagen. 56: 228-244. http://dx.doi.org/10.1002/em.21928

Hnizdo E and Vallyathan V (2003). Chronic obstructive pulmonary disease due to occupational exposure to silica dust: a review of epidemiological and pathological evidence. Occup. Environ. Med. 60: 237-243. http://dx.doi.org/10.1136/ oem.60.4.237

Hu S, Zhao H, Yin XJ and Ma JK (2007). Role of mitochondria in silica-induced apoptosis of alveolar macrophages: inhibition of apoptosis by rhodamine 6G and N-acetyl-L-cysteine. J. Toxicol. Environ. Health A 70: 1403-1415. http://dx.doi.org/10.1080/15287390701251990

Ishihara Y, Iijima H, Matsunaga K, Fukushima T, et al. (2002). Expression and mutation of p53 gene in the lung of mice intratracheal injected with crystalline silica. Cancer Lett. 177: 125-128. http://dx.doi.org/10.1016/S0304$\underline{3835(01) 00779-0}$

Johnston CJ, Driscoll KE, Finkelstein JN, Baggs R, et al. (2000). Pulmonary chemokine and mutagenic responses in rats after subchronic inhalation of amorphous and crystalline silica. Toxicol. Sci. 56: 405-413. http://dx.doi.org/10.1093/ $\underline{\text { toxsci/56.2.405 }}$

Genetics and Molecular Research 15 (3): gmr.15039005 
Kim HA, Choi YJ, Kim KW, Lee BT, et al. (2012). Nanoparticles in the environment: stability and toxicity. Rev. Environ. Health 27: 175-179. http://dx.doi.org/10.1515/reveh-2012-0025

Kipen HM and Laskin DL (2005). Smaller is not always better: nanotechnology yields nanotoxicology. Am. J. Physiol. Lung Cell. Mol. Physiol. 289: L696-L697.http://dx.doi.org/10.1152/ajplung.00277.2005

Leist M and Nicotera P (1997). The shape of cell death. Biochem. Biophys. Res. Commun. 236: 1-9. http://dx.doi. org/10.1006/bbrc. 1997.6890

Leist M, Kuhnle S, Single B and Nicotera P (1998). Differentiation between apoptotic and necrotic cell death by means of the BM cell death detection ELISA or Annexin V staining. Biochemica 2: 25-28.

Lim Y, Kim JH, Kim KA, Chang HS, et al. (1999). Silica-induced apoptosis in vitro and in vivo. Toxicol. Lett. 108: 335 339. http://dx.doi.org/10.1016/S0378-4274(99)00107-1

Lin W, Huang YW, Zhou XD and Ma Y (2006). In vitro toxicity of silica nanoparticles in human lung cancer cells. Toxicol. Appl. Pharmacol. 217: 252-259. http://dx.doi.org/10.1016/j.taap.2006.10.004

Mosmann T (1983). Rapid colorimetric assay for cellular growth and survival: application to proliferation and cytotoxicity assays. J. Immunol. Methods 65: 55-63.http://dx.doi.org/10.1016/0022-1759(83)90303-4

Mu Q, Hondow NS, Krzemiński L, Brown AP, et al. (2012). Mechanism of cellular uptake of genotoxic silica nanoparticles. Part. Fibre Toxicol. 9: 29. http://dx.doi.org/10.1186/1743-8977-9-29

Muhle H, Kittel B, Ernst H, Mohr U, et al. (1995). Neoplastic lung lesions in rat after chronic exposure to crystalline silica. Scand. J. Work Environ. Health 21 (Suppl 2): 27-29.

Nagalakshmi R, Nath J, Ong T and Whong WZ (1995). Silica-induced micronuclei and chromosomal aberrations in Chinese hamster lung (V79) and human lung (Hel 299) cells. Mutat. Res. 335: 27-33. http://dx.doi.org/10.1016/0165$\underline{1161(95) 90061-6}$

Napierska D, Thomassen LC, Lison D, Martens JA, et al. (2010). The nanosilica hazard: another variable entity. Part. Fibre Toxicol. 7: 39. http://dx.doi.org/10.1186/1743-8977-7-39

Nehls P, Seiler F, Rehn B, Greferath R, et al. (1997). Formation and persistence of 8-oxoguanine in rat lung cells as an important determinant for tumor formation following particle exposure. Environ. Health Perspect. 105 (Suppl 5): 1291-1296. http://dx.doi.org/10.1289/ehp.97105s51291

Nel A, Xia T, Mädler L and Li N (2006). Toxic potential of materials at the nanolevel. Science 311: 622-627. http://dx.doi. org/10.1126/science.1114397

Olive PL, Banáth JP and Durand RE (1990). Heterogeneity in radiation-induced DNA damage and repair in tumor and normal cells measured using the "comet" assay. Radiat. Res. 122: 86-94.http://dx.doi.org/10.2307/3577587

Park MV, Lynch I, Ramírez-García S, Dawson KA, et al. (2011a). In vitro evaluation of cytotoxic and inflammatory properties of silica nanoparticles of different sizes in murine RAW 2647 macrophages. J. Nanopart. Res. 13: 67756787. http://dx.doi.org/10.1007/s11051-011-0586-6

Park MV, Verharen HW, Zwart E, Hernandez LG, et al. (2011b). Genotoxicity evaluation of amorphous silica nanoparticles of different sizes using the micronucleus and the plasmid lacZ gene mutation assay. Nanotoxicology 5: 168-181. http://dx.doi.org/10.3109/17435390.2010.506016

Santarelli L, Recchioni R, Moroni F, Marcheselli F, et al. (2004). Crystalline silica induces apoptosis in human endothelial cells in vitro. Cell Biol. Toxicol. 20: 97-108. http://dx.doi.org/10.1023/B:CBTO.0000027935.45070.75

Schins RP, Knaapen AM, Cakmak GD, Shi T, et al. (2002). Oxidant-induced DNA damage by quartz in alveolar epithelial cells. Mutat. Res. 517: 77-86. http://dx.doi.org/10.1016/S1383-5718(02)00039-6

Schottenfeld D and Beebe-Dimmer J (2006). Chronic inflammation: a common and important factor in the pathogenesis of neoplasia. CA Cancer J. Clin. 56: 69-83. http://dx.doi.org/10.3322/canjclin.56.2.69

Singh NP, McCoy MT, Tice RR and Schneider EL (1988). A simple technique for quantitation of low levels of DNA damage in individual cells. Exp. Cell Res. 175: 184-191. http://dx.doi.org/10.1016/0014-4827(88)90265-0

Srivastava JK and Gupta S (2006). Tocotrienol-rich fraction of palm oil induces cell cycle arrest and apoptosis selectively in human prostate cancer cells. Biochem. Biophys. Res. Commun. 346: 447-453. http://dx.doi.org/10.1016/j. bbrc.2006.05.147

Tarantini A, Huet S, Jarry G, Lanceleur R, et al. (2015). Genotoxicity of synthetic amorphous silica nanoparticles in rats following short-term exposure. Part 1: oral route. Environ. Mol. Mutagen. 56: 218-227. http://dx.doi.org/10.1002/ $\underline{\mathrm{em} .21935}$

Thibodeau M, Giardina C and Hubbard AK (2003). Silica-induced caspase activation in mouse alveolar macrophages is dependent upon mitochondrial integrity and aspartic proteolysis. Toxicol. Sci. 76: 91-101.http://dx.doi.org/10.1093/ $\underline{\text { toxsci } / \mathrm{kfg} 178}$

Thibodeau MS, Giardina C, Knecht DA, Helble J, et al. (2004). Silica-induced apoptosis in mouse alveolar macrophages is initiated by lysosomal enzyme activity. Toxicol. Sci. 80: 34-48. http://dx.doi.org/10.1093/toxsci/kfh121

Genetics and Molecular Research 15 (3): gmr.15039005 
Tice RR, Agurell E, Anderson D, Burlinson B, et al. (2000). Single cell gel/comet assay: guidelines for in vitro and in vivo genetic toxicology testing. Environ. Mol. Mutagen. 35: 206-221. http://dx.doi.org/10.1002/(SICI)10982280(2000)35:3<206::AID-EM8>3.0.CO;2-J

Uboldi C, Giudetti G, Broggi F, Gilliland D, et al. (2012). Amorphous silica nanoparticles do not induce cytotoxicity, cell transformation or genotoxicity in Balb/3T3 mouse fibroblasts. Mutat. Res. 745: 11-20. http://dx.doi.org/10.1016/j. mrgentox.2011.10.010

van der Zande M, Vandebriel RJ, Groot MJ, Kramer E, et al. (2014). Sub-chronic toxicity study in rats orally exposed to nanostructured silica. Part. Fibre Toxicol. 11: 8. http://dx.doi.org/10.1186/1743-8977-11-8

Wang JJ, Sanderson BJ and Wang H (2007). Cytotoxicity and genotoxicity of ultrafine crystalline $\mathrm{SiO}_{2}$ particulate in cultured human lymphoblastoid cells. Environ. Mol. Mutagen. 48: 151-157. http://dx.doi.org/10.1002/em.20287

Wang L, Bowman L, Lu Y, Rojanasakul Y, et al. (2005). Essential role of p53 in silica-induced apoptosis. Am. J. Physiol. Lung Cell. Mol. Physiol. 288: L488-L496. http://dx.doi.org/10.1152/ajplung.00123.2003

Warheit DB, Webb TR, Colvin VL, Reed KL, et al. (2007). Pulmonary bioassay studies with nanoscale and fine-quartz particles in rats: toxicity is not dependent upon particle size but on surface characteristics. Toxicol. Sci. 95: 270-280. http://dx.doi.org/10.1093/toxsci/kfl128

Wu M (2005). DNA repair proteins as molecular therapeutics for oxidative and alkylating lung injury. Curr. Gene Ther. 5: 225-236. http://dx.doi.org/10.2174/1566523053544245

Xue ZG, Zhu SH, Pan Q, Liang DS, et al. (2006). Biotoxicology and biodynamics of silica nanoparticle. Zhong Nan Da Xиe Xue Bao Yi Xue Ban 31: 6-8.

Yamano Y, Kagawa J, Hanaoka T, Takahashi T, et al. (1995). Oxidative DNA damage induced by silica in vivo. Environ. Res. 69: 102-107.http://dx.doi.org/10.1006/enrs.1995.1031

Genetics and Molecular Research 15 (3): gmr.15039005 